\title{
Flipped Classroom
}

\author{
Mauro Nunez ${ }^{1 *}$ and Esteban Araya ${ }^{2}$ \\ ${ }^{1}$ Associate Professor of Medicine \& Surgery, Universidad Ciencias Medicas (UCIMED), Consultant Department of Orthopedic Surgery, Hip \& Pelvic Unit, \\ Hospital del Trauma, Central America
}

${ }^{2}$ Associate Professor of Medicine \& Surgery, Universidad Ciencias Medicas (UCIMED), Consultant Department of Orthopedic Surgery, Spine Unit, Hospital del Trauma, Costa Rica, Central America.

Submission: October 30, 2017; Published: November 10, 2017

*Corresponding author: Mauro Nunez, Associate Professor of Medicine \& Surgery, Universidad Ciencias Medicas (UCIMED), Consultant Department of Orthopedic Surgery, Hip \& Pelvic Unit, Hospital del Trauma, Uruca 1000 San Jose, Costa Rica, Central America,

Email: nunezmauro@yahoo.com

\author{
Abstract \\ Flipped Classroom is a pedagogical resource that may improve adult learning by delivering educational content outside the classroom and \\ performing more complex classroom activities.
}

Keywords: Flipped Classroom; Adult Education; Adult Learning; Teaching Styles

\section{Introduction}

Flipped Classroom is a pedagogical resource that reverses the traditional learning environment by delivering educational content outside the classroom.

\section{Discussion}

In the Flipped Classroom, students read, view lectures, videos, or other resources from home, and then conduct a more complex classroom activity ranging from group discussion on a topic to a problem case solution, applying the concepts learned at home $[1,2]$. In the classroom with traditional teaching style, lessons usually focus on an explanation of content using a lecture style. Class discussions usually focus on the teacher, who controls the flow of the conversation, while student participation is very limited. The Flipped Classroom intentionally changes the instructions to a student-centered model, in this model the class time explores the topics in greater depth and creates significant learning opportunities, while educational technologies such as online videos are used to deliver content outside the classroom [3]. The Flipped Classroom also redefines classroom activities, which may include more participatory activities to engage students with educational content. Because this type of active learning enables highly differentiated teaching, more class time can be devoted to higher order thinking skills, such as finding solutions to problems raised through group work, research, and discussion $[4,5]$.

\section{Conclusion}

To conclude, the Flipped Classroom is an attractive didactic resource to be considered as part of the training activities of university students in health science, encouraging the active participation in the acquisition of knowledge and the organization of this knowledge as they participate in activities with their peers.

\section{Disclosure}

The authors did not receive any outside funding or grants in support for the preparation of this work. Neither he nor a member of his immediate family received any payments or benefits or a commitment or agreement to provide such benefits for commercial entity.

\section{References}

1. Abeysekera, Lakmal, Phillip Dawson (2015) Motivation and cognitive load in the flipped classroom: definition, rationale and a call for research. Higher Education Research \& Development 34(1): 1-14.

2. Alvarez B (2011) Flipping the classroom: Homework in class, lessons at home. Education Digest: Essential Readings Condensed For Quick Review 77(8): 18-21.

3. Kaw A, Hess M (2007) Comparing Effectiveness of Instructional Delivery Modalities in an Engineering Course Autar Kaw and Melinda Hess. International Journal of Engineering Education 23(3): 508-516.

4. Ryback D, Sanders J (1980) Humanistic versus traditional teaching styles and student satisfaction. Journal of Humanistic Psychology 20(87): 87-90.

5. Strayer JF (2012) How learning in an inverted classroom influences cooperation, innovation and task orientation. Learning Environments Research 15(2): 171-193. 
This work is licensed under Creative Commons Attribution 4.0 Licens DOI: 10.19080/OAJS.2017.06.555697

\section{Your next submission with Juniper Publishers} will reach you the below assets

- Quality Editorial service

- Swift Peer Review

- Reprints availability

- E-prints Service

- Manuscript Podcast for convenient understanding

- Global attainment for your research

- Manuscript accessibility in different formats

( Pdf, E-pub, Full Text, Audio)

- Unceasing customer service

Track the below URL for one-step submission https://juniperpublishers.com/online-submission.php 